\title{
Risk of Mortality Caused by Silicosis and Lung Cancer: A Study on Ceramic Tile Factory Workers
}

\author{
Mohammad Nourmohammadi', Ayda Fallah Asadi², Alireza Mosavi Jarrahi, \\ Saeed Yari ${ }^{4}$
}

${ }^{1}$ Assistant Professor of Occupational Health Engineering Department, Health College, Mashhad University of Medical Sciences, Mashhad, Iran. ${ }^{2}$ Nursing and Midwifery Department, Qazvin University of Medical Sciences, Qazvin, Iran. ${ }^{3}$ School of Medicine, Shahid Beheshti University of Medical Sciences, Tehran, Iran. ${ }^{4}$ School of Health Science, Shahid Beheshti University of Medical Sciences, Tehran, Iran.

\begin{abstract}
Exposure to silica dust may be considered as an important hazard in the tile industry. The aim of this research was to determine workers' exposure to crystalline silica dust and assess the relative risk of silicosis and the excess lifetime risk of mortality from lung cancer in tile industry. The visible spectroscopy, based on the NIOSH method 7601, was employed to the do sampling and analysis. For estimate the rate of silicosis relate mortality and the excess lifetime risk of mortality from lung cancer the Mannetje and rice model used. The highest average of the exposure rate to silica were in Stone crusher $\left(0 / 43 \mathrm{mg} / \mathrm{m}^{3}\right)$ section and press section while the lowest average of the exposure rate to free silica was in packaging section $\left(0 / 12 \mathrm{mg} / \mathrm{m}^{3}\right) .95$ percent of the study samples scored above the occupational exposure limit $0.05 \mathrm{mg} / \mathrm{m}^{3} \mathrm{NIOSH}$ standard.
\end{abstract}

Keywords: Lung Cancer- Silicosis- Risk Assessment- Ceramic Tile

Asian Pac J Environment and Cancer, 1 (1), 55-58

\section{Introduction}

Silica is the most widely found mineral on the earth crust, which consists of a silicon atom and two oxygen atoms. Silica exists in two forms, crystalline (quartz, cristobalite, and tridymite) and amorphous. Many workers in various industries exposed to silica such as mining [1], sandblast [2], foundry [3], and construction activitis [4-5]. Exposure to crystalline silica causes chronic lung inflammation which, in turn, could lead to pulmonary fibrosis as well as silicosis. Although the specific mechanism leading to the disease has yet to be recognized, there are plenty of theories among which damaging the alveolar macrophages is the most agreed upon one. As the result of exposure to crystalline silica, the silica particles are absorbed by the microphages in the workers' lung alveolar, which then start phagocytizing them. It will damage cellular lysosomal membrane which, indeed, caused by the interaction between crystalline silica and hydrogen ions in the membrane [6-7]. The International Agency for Research on Cancer (IARC) categorized silica as a human carcinogen in 1996; however the
Submission Date: 08/13/2018 Acceptance Date: 10/14/2018

carcinogenic potential of silica was subject to uncertainties due to a number of evidences. But, following to another examination conducted by IARC, mainly focusing on dose-response and cohort studies in 2009, it was revealed that inhaled silica, in form of quartz and cristobalite, in the workplace could be carcinogenic to humans and, therefore, silica was classified as the class 1 (A1) human carcinogen [8-10]. Silica, both repairable and irrespirable, can produce adverse health effects. Concerning the effect of respirable silica, silicosis is one of the most dangerous diseases reported so far. National Institute for Occupational Safety and Health (NIOSH) estimates that more than 1.7 million American workers [11], more that 2 million European workers [11], and more than 23 million Chinese workers are exposed to silica [12]. Furthermore, hundreds of workers have become incapacitated by this disease as well as Bronchitis. Exposure to silica dust is considered the biggest risk factor in the construction industry [13-14]. There is surfactant secreting, synthesis type II cells in the lung alveolar. Damage to alveolar type I cells provokes type II cells proliferation to replace the damaged type I cells. Inhaled quartz makes hyperplastic and hypertrophic

Corresponding Author:

Dr. Saeed Yari

School of Health Science, Shahid Beheshti University of Medical Sciences, Tehran, Iran.

Email: Smaeedy@gmail.com 
changes in alveolar type II cells. This process makes the proliferative changes permanent and, at the end, leads to development of tumor in alveolar cells. Studies conducted on animal cells show that crystalline silica is capable of breaking down DNA threads and brings chromosomal damage. If the damage incurred to DNA is so severe that brings about genetic changes, it will cause unwanted cell proliferation and respiratory system cancer [15]. Saki and colleagues, on their study on the ceramic workers, showed that the ceramic industry increases the risk of silicosis, proportionally increased by age and duration of contact with silica [16]. Anlar and colleagues carried out a study on Turkish ceramic workers to assess their health in which blood indices, pulmonary enzymes, levels of mercury, and pulmonary indices were employed to compare the ceramic workers with control group. As revealed by the results, blood indices like ALT, AST, PLT, WBC, and $\mathrm{CR}$ as well as the levels of mercury were reported to be higher among the ceramic workers than the control group while the levels of hematocrit were lower in the ceramic workers than the control group. Thirty eight workers were diagnosed with silicosis, 9 were suspected to have silicosis, and only 52 were healthy [17]. The risk assessment, over the recent years, has been raised as one of the most significant issues regarding the control of occupational diseases. Assessing risk of mortality caused by silicosis, in this study, is estimated based on Mannetje model, in which the cumulative exposure is in $\mathrm{mg} / \mathrm{m}^{3}$ and $\mathrm{X}$ is the duration of exposure (in year) within various age groups. The risk of mortality caused by silicosis is assessed by calculation of the cumulative exposure first and, then, inserting this amount into in the model [18]. The risk of silicosis was assessed through the model proposed by Mannetje, according to which the relative risk of mortality for 5-year cumulative exposure (in $\mathrm{mg} / \mathrm{m}^{3}$ ) was 13.7 percent per thousand workers while the actual risk of mortality, estimated through performing cohort study on 3010 Chinese workers, was 33.7 percent [19]. Considering the inevitability of exposure to silica for ceramic tile workers, this study aims at assessing the concentration of silica exposure, risk of silicosis posed by exposure to the crystalline silica, and mortality rate of lung cancer among the ceramic tile workers.

\section{Sampling and analysis}

First, the occupational exposure to the free silica was examined among workers of a ceramic tile factory and, consequently, 50 samples were gathered. The visible spectroscopy, based on the NIOSH method 7601, was employed to the do sampling and analysis. Sampling equipment used in this method included: separate sampling pump (SKC LTD), 10-mm nylon cyclone, and membrane filter $(0.8 \mu \mathrm{m}$ pore size, $47 \mathrm{~mm}$ diameter $)$. Before and after the sampling, filters were both placed in the desiccators for 24 hours to lose the moisture and weighted by a balance (with precision weight Scale of $0.0001 \mathrm{~g}$ ). The pump flow was set on $1 / 7 \mathrm{~L} / \mathrm{min}$ and the sampling was done [20].

\section{Risk assessment}

The risk of exposure to the free silica was assessed by employing the model developed by Mannetje to estimate the mortality caused by silica exposure in a 10 -year period [18]. The cumulative exposure to silica, in this study, was considered to be within the range of 0 to 0.99 and above $18.10\left(\mathrm{mg} / \mathrm{m}^{3}\right)$ per year. Indeed, the occupational history of exposure and concentration of silica (in $\mathrm{mg} / \mathrm{m}^{3}$ ) are the two main parameters in the model. In addition to probability of dying by silicosis, the mortality rate of lung cancer is calculated through Rice (and colleagues) linear model and geometric mean of exposure to silica according to following formula, in which GM is the geometric mean of workers' exposure to silica [21].

\section{$\mathrm{A}=0.77+373.69 \times \mathrm{GM}$}

Descriptive statistical tests were used to calculate mean and standard arithmetic and geometric deviation of exposure in various sections of the industry. Moreover, Kolmogorov-Smirnov and t-test were conducted to check the normality and difference between individual exposure rate and national exposure limit respectively. SPSS, version 19, was used to do these tests.

\section{Results}

All subjects of the study were male, with the median age of 35 . Table 1 shows the results of measuring arithmetic and geometric mean of exposure to the free silica for workers in various sections of the tile factory. As revealed by the results, the highest average of the exposure rate to silica were in Stone crusher section and press section while the lowest average of the exposure rate to free silica was in packaging section. According to NIOSH and Iranian Occupational Health Committee, occupational exposure limit to the free silica is $0.05 \mathrm{mg} / \mathrm{m}^{3}(\mathrm{P}<0.001)$ and 95 percent of the study samples scored above the occupational exposure limit.

Additionally, the risk of mortality caused by silicosis among tile workers (based on Manneje model) is illustrated in the Table 2 .

\section{Risk of mortality caused by lung cancer}

Results of estimating risk of mortality caused by lung cancer among tile workers exposed to silica dusts are depicted in the Table 3. The risk of mortality caused

Table 1. Results of Measuring Exposure to the Crystaline Silica $\left(\mathrm{mg} / \mathrm{m}^{3}\right)$ in Various Sections of the Factory

\begin{tabular}{lcccc}
\hline groups & No. of samples & $\begin{array}{c}\text { Mean } \\
\left(\mathrm{mg} / \mathrm{m}^{3}\right)\end{array}$ & $\begin{array}{c}\mathrm{GM} \\
\left(\mathrm{mg} / \mathrm{m}^{3}\right)\end{array}$ & $\mathrm{SD}$ \\
\hline Stone crusher & 7 & $0 / 43$ & $0 / 33$ & $0 / 11$ \\
Press & 10 & $0 / 33$ & $0 / 21$ & $0 / 13$ \\
Preparation of powder & 10 & $0 / 32$ & $0 / 26$ & $0 / 16$ \\
Glaze line & 10 & $0 / 27$ & $0 / 18$ & $0 / 09$ \\
Furnace & 10 & $0 / 16$ & $0 / 11$ & $0 / 08$ \\
packing & 10 & $0 / 12$ & $0 / 1$ & $0 / 05$ \\
SUM & 57 & $0 / 45$ & $0 / 196$ & $0 / 23$ \\
\hline
\end{tabular}


Table 2. Risk of Mortality Caused by Silicosis among Tile Workers, Based on Cumulative Exposure ( $\mathrm{mg} / \mathrm{m}^{3} \mathrm{per}$ year) to the Crystaline Silica (Risk Assessment Based on Mannetje Model)

\begin{tabular}{lcc}
\hline Cumulative exposure & $\begin{array}{c}\text { Relative risk of silicosis-related } \\
\text { mortality based on Mannetje et al model }\end{array}$ & No. of exposed worker's in ceramic industry (\%) \\
\hline $0-0 / 99$ & 1 & $(24.5) 14$ \\
$0 / 99-1 / 97$ & $3 / 4$ & $(8 / 77) 5$ \\
$1 / 97-2 / 87$ & $6 / 2$ & $(12 / 2) 7$ \\
$2 / 87-4 / 33$ & $9 / 4$ & $(26 / 3) 15$ \\
$4 / 33-7 / 12$ & $13 / 7$ & $(7) 4$ \\
$7 / 12-9 / 58$ & $6 / 22$ & $(12.2) 7$ \\
$9 / 58-13 / 21$ & 24 & $(7) 4$ \\
$13 / 21-15 / 89$ & $40 / 2$ & $(1 / 7) 1$ \\
$15 / 89-28 / 1$ & $52 / 1$ & 0 \\
\hline
\end{tabular}

Table 3. Risk of Mortality Caused by Lung Cancer among the Tile Workers Based on Linear Regression of Rice and Colleagues Model

\begin{tabular}{lccc}
\hline Area & No. of samples & $\mathrm{GM}\left(\mathrm{mg} / \mathrm{m}^{3}\right)$ & The excess lifetime risk of mortality from lung cancer \\
\hline Stone crusher & 7 & $0 / 33$ & 124 \\
Press & 10 & $0 / 21$ & 79 \\
Preparation of powder & 10 & $0 / 26$ & 97 \\
Glaze line & 10 & $0 / 18$ & 68 \\
Furnace & 10 & $0 / 11$ & 34 \\
packing & 10 & $0 / 16$ & 41 \\
SUM & 57 & $0 / 196$ & 74 \\
\hline
\end{tabular}

by lung cancer was calculated through employing Rice (and colleagues) Linea model and the results show that 74 to 124 out of every 1000 workers, exposed to silica, were in danger of developing lung cancer.

\section{Discussion}

This paper aims at calculating the exposure rate of workers to crystalline silica in a ceramic tile factory as well as assessing the risk of mortality caused by silicosis and lung cancer. It is just an attempt to estimate the mortality rate among workers exposed to silica. The calculated average exposure to silica, in this study, is above the standard exposure limit in England $\left(0.09 \mathrm{mg} / \mathrm{m}^{3}\right)$ and Iran $\left(0.05 \mathrm{mg} / \mathrm{m}^{3}\right)$ as well. Azari and colleagues also assessed the risk of Tehran construction workers in their study and showed that their exposure to free silica was above the standard limit, which is in accordance with the result of this study [22]. Moreover, in the study performed by Nourmohammadi and colleagues to assess the exposure rate to free silica in building demolition, it was reported that the average exposure was above the occupational exposure limit in 80 percent of sample [5]. Such studies indicate that workers are widely exposed to free silica in the construction industry [23-24]. A broad range of studies have been carried out to explore the relation between exposure to silica and mortality caused by silicosis and lung cancer, in which a significant relationship was found between the two. The risk of mortality caused by silicosis and lung cancer among the ceramic tile workers has been assessed in this study based on Mannetje model and Rice (and colleagues) model respectively. According to the model developed by Mannetje and coleagues, 21 percent of workers exposed to silica are in range of 0 to 0.99 , which translates to 1 death out of every 1000 , which is in line with what we've found in our study concerning the risk of mortality caused by exposure to silica [10]. Chen and colleagues, in their prospective study, took a look at 4 Chinese small mines to investigate mortality rate, caused by exposure to silica and its mixed particles, on 7000 people. The results indicate that death due to lung cancer is the third most common cause of death among the workers, contributing to 7 percent of deaths in all samples. The death rate, in our study, has been also calculated to be 1 in every 1000 workers, which could highlight the importance of assessing the exposure to silica and controlling it [14]. In the study conducted by Finkelstein in 2000, the standard exposure limit and the risk of cancer due to silica particle were put under careful examination and it was revealed that if the occupational exposure limit, set by OSHA, was $0.1 \mathrm{mg} / \mathrm{m}^{3}$, the risk of lung cancer would be 30 percent and if occupational exposure limit, set by the NIOSH, was $0.05 \mathrm{mg} / \mathrm{m}^{3}$, the risk of lung cancer would drop under 5 percent. Given that the occupational exposure limit in Iran is similar to what set by NIOSH, and the risk of death due to the cancer has been calculated in the range of 0.9 to 40 percent, it could be concluded that the standard exposure limit have been set properly. However, the range gap may be reduced and coming closer to the international standards 
by taking the importance of controlling and monitoring into account [15]. Performing a cohort study, Yuewei Liu and colleagues assessed the risk of cancer death due to exposure to silica among 34,000 workers over 44 years, within which 542 deaths due to the lung cancer were reported. Moreover, Steenland and colleagues also have been examining the risk of lung cancer in their detailed study over 10 years, since 2001. The two given studies came at the same results, both concerning mortality and cancer percentage, as we found in ours, which underlines the gravity of exposure to this substance and necessity of regular monitoring to reduce the risk of cancer caused by the silica exposure [16-17].

In conclusion, assessing risk of morality caused by silica and silicosis indicate the importance of this substance and exposure to it. As revealed in our study as well as other studies, the morality risk of these two parameters are so high for silica and necessitate an urgent change in assessment, rules, engineering and managerial control methods relating to this substance. In addition, the standard exposure limit also needs further reviews and updates.

\section{References}

1. Ehrlich RI. Tuberculosis, mining and silica. Occup Env Med. 2018;75(11):763-4.

2. Sierra-Calderon DD, Severiche-Sierra CA, Bedoya-Marrugo EA, Meza-Aleman M de J, Espinosa-Fuentes EA. Silice in the Sandblasting Industry: a review from Occupational Safety and Health. Int J Appl Eng Res. 2018;13(8):6274-81.

3. Tong R, Cheng M, Ma X, Yang Y, Liu Y, Li J. Quantitative health risk assessment of inhalation exposure to automobile foundry dust. Environ Geochem Health. 2019;1-15.

4. Yari S, Falah-asadi A, Normohammadi M. Occupational and Environmental Cancer. 2018;1(1):5-13.

5. Kakooei H, Nourmohammadi M, Mohammadian Y, Zarei E, Zokaei M. Assessment of occupational exposure to crystalline silica during demolition of buildings in Tehran. Iran Occup Heal. 2014;11(2):63-9.

6. Yari S, Asadi AF, Jarrahi AM. CARcinogen EXposure: CAREX. 2018;1(1):27-33.

7. Sato T, Shimosato T, Klinman DM. Silicosis and lung cancer: current perspectives. Lung Cancer Targets Ther. 2018;9:91.

8. Iarc. International Agency for Research ON Cancer Iarc Monographs on The Evaluation of Carcinogenic Silica, Some Silicates, Coal Dust. Int Agency Res O N Cancer Iarc Monogr Eval Carcinog Silica, Some Silic, Coal Dust. 1997.

9. Borm PJA, Fowler P, Kirkland D. An updated review of the genotoxicity of respirable crystalline silica. Part Fibre Toxicol. 2018;15(1):23.

10. Yari S, Asadi AF, Varmazyar S. Assessment of SemiQuantitative Health Risks of Exposure to Harmful Chemical Agents in the Context of Carcinogenesis in the Latex Glove Manufacturing Industry. Asian Pacific J Cancer Prev. 2017;17(sup3):205-11.

11. Review NH. Silica_prelim 1-17-02.vp. 2002;(April):1-145. Available from: papers://d55905fe-9b37-4a1d-b1da1e391d512486/Paper/p345

12. Liu Y, Zhou Y, Hnizdo E, Shi T, Steenland K, He X, et al. Total and cause-specific mortality risk associated with lowlevel exposure to crystalline silica: A 44-year cohort study from China. Am J Epidemiol. 2017;186(4):481-90.
13. Park H, Hwang E. 0073 Respirable dust and crystalline silica exposure among concrete finishing workers in construction industry. BMJ Publishing Group Ltd; 2017.

14. Carmichael G. Deadly Dust: Reducing the Risks of Silica Dust in Glass Working Operations. In: 78th Conference on Glass Problems: Ceramic Engineering and Science Proceedings, Issue 1. Wiley Online Library; 2018. p. 165-8.

15. Joshi G. Silica Generated Reactive Oxygen Species, Phagolysosomal Leakage and Cell Death in Alveolar Macrophages. 2015;

16. Sakar A, Kaya E, Celik P, Gencer N, Temel O, Yaman N, et al. Evaluation of silicosis in ceramic workers. Tuberk Toraks. 2005;53(2):148-55.

17. Anlar HG, Bacanli M, İritaş S, Bal C, Kurt T, Tutkun E, et al. Effects of occupational silica exposure on oxidative stress and immune system parameters in ceramic workers in Turkey. J Toxicol Environ Heal Part A. 2017;80(1315):688-96.

18. 'T Mannetje A, Steenland K, Attfield M, Boffetta P, Checkoway H, DeKlerk N, et al. Exposure-response analysis and risk assessment for silica and silicosis mortality in a pooled analysis of six cohorts. Occup Environ Med. 2002;59(11):723-8.

19. Chen W, Liu Y, Wang H, Hnizdo E, Sun Y, Su L, et al. Long-term exposure to silica dust and risk of total and causespecific mortality in Chinese workers: a cohort study. PLoS Med. 2012;9(4):e1001206.

20. National Institute for Occupational Safety and Health. Silica, Crystalline by VIS: Method 7601. Man Anal Methods, Fourth Ed. 2003;7(3):2-7.

21. Park R, Rice F, Stayner L, Smith R, Gilbert S, Checkoway $\mathrm{H}$. Exposure to crystalline silica, silicosis, and lung disease other than cancer in diatomaceous earth industry workers: A quantitative risk assessment. Occup Environ Med. 2002;59(1):36-43.

22. Azari MR, Rokni M, Salehpour S, Mehrabi Y, Jafari MJ, Moaddeli AN, et al. Risk assessment of workers exposed to crystalline silica aerosols in the east zone of Tehran. Tanaffos. 2009;8(3):43-50.

23. Blanc PD, Järvholm B, Torén K. Prospective risk of rheumatologic disease associated with occupational exposure in a cohort of male construction workers. Am J Med. 2015;128(10):1094-101.

24. West GH, Lippy BE, Cooper MR, Marsick D, Burrelli LG, Griffin KN, et al. Toward responsible development and effective risk management of nano-enabled products in the US construction industry. J nanoparticle Res. 2016;18(2):49.

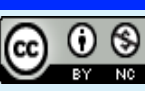

This work is licensed under a Creative Commons AttributionNon Commercial 4.0 International License. 